\title{
Rural Urban Migration in Mountain Areas and its Compatibility with Natural, Social and Economic Regimes: A Case of Kıbrıscık District, Bolu Province, Turkey
}

\author{
Dağllk Alanlarda Kırdan Kente Göçün Doğal, Sosyal ve Ekonomik Rejimlerle \\ Uyumluluğu: Türkiye/Bolu İli Klbrısclk İlçesi Örneği \\ Ashfaq Ahmad KHAN ${ }^{*}$, Mehmet SOMUNCU ${ }^{2}$ \\ ${ }^{I}$ Department of Geography Institute of Social Sciences, Ankara University, Ankara, Turkey \\ ${ }^{2}$ Department of Geography, Faculty of Letters, Ankara University, Ankara, Turkey
}

\begin{abstract}
Mountainous areas of world are facing a number of problems like poverty, out migration, deficiency of productive crop land and decreased livestock activities. Present research examines the relationship between environmental degradation and out migration in mountainous area of Bolu Province, Turkey. District Kibriscik of Bolu province which is located inside the Koroglu Mountains of Western Black Sea Region, including 22 villages and city center has been selected as research area. Data was collected through primary and secondary sources. A household questionnaire survey was conducted with 201 families based on stratified simple random sampling. The qualitative data was collected through personal observations and in-depth interviews with residents of different age groups and representatives of civil society organizations. Furthermore, secondary data was collected from Turkish Directorate General of Forest, Turkish statistical Institute and District Agriculture Office, Kibriscik. Statistical analysis was performed to interpret the collected data. Results revealed that population of the research area have decreased significantly in recent years due to lack of employment opportunities in the area. Out migration was proved beneficial in terms of environmental stability as it reduced pressure on already fragile mountain ecosystem. It was found that forest-cover increased by $8.8 \%$ from 1968 to 1986 which furthermore increased by $1.65 \%$ from 1986 to 2005. Our results also showed that increase in forest and pasture land decreased erosion significantly as compared to the previous years. Moreover, out migration of young generation in search of better living standards resulted in increase of economically inactive older ones. As a result, serious decrease in livestock activity is observed in the area where animal husbandry once served as major economic resource. Similar situations in many mountainous areas of Turkey has affected the country`s overall supply of dairy products. It is therefore necessary to formulate policies that emphasize economic and environmental sustainability in mountain areas.
\end{abstract}

Key words: Environmental conservation, population dynamics, sustainable development, mountainous areas, Turkey.

Özet: Dünyadaki dağllk alanlar yoksulluk, göç, tarımsal arazi kıtlı̆̆l ve hayvancıllk faaliyetlerinin azalması gibi sorunlarla karşılaşmaktadır. Bu makalenın amacı, Türkiye'nin Bolu ilindeki dağlık alanlarda, çevresel bozulma ve kırdan kente göç arasındaki ilişkiyi araştırmaktır. Araştırma alanı olarak, Köroğlu Dağları içinde bulunan Bolu ilinin Kıbrıscık ilçesinde, 22 köy ve ilçe merkezi de dâhil olmak üzere geniş bir bölge seçilmiştir. Araştırmada gereken veri birincil ve ikincil kaynaklar aracılı̆̆ıyla toplanmıştır. Tabakalı basit örnekleme yöntemine dayalı olarak 201 aileye hane halkı anketi uygulanmıştır. Nitel veriler ise, kişisel gözlem ve farklı yaş gruplarına ait yerel kişiler ile sivil toplum örgütleri temsilcileri ile yapılan derinlemesine görüşmeler yoluyla toplanmıştır. Ayrıca, Orman Genel Müdürlü̈̆̈̈, Türkiye İstatistik Kurumu ve Kıbrısçık İlçe Tarım Müdürlüğü'nden ikincil veriler elde edilmiştir. Veri analizi sonuçlarına gore, son yıllarda bölgedeki istihdam olanaklarının eksikliği nedeniyle araştırma alanının nüfusunda önemli ölçüde azalma olduğu ortaya çıkmıştır. Ancak kırdan kente göç, kırılgan dağ ekosistemi üzerindeki baskıyı azaltmış ve çevresel istikrar açısından yararlı bir durum ortaya çıkarmıştır. Araştırma alanındaki orman örtüsünün 1968- 1986 yılları arasında \% 8,8; 1986-2005 yıllar arasında ise \% 1,65 arttı̆̆ saptanmıştır. Araş̧ırma

\footnotetext{
*Corresponding author: ashfakgeo@gmail.com
} 
bulgularına göre orman ve mera arazisindeki artış, önceki yıllarla karşılaştırıldığında, erozyonun önemli ölçüde azaldı̆̆ı ortaya çıkmıştır. Ancak, daha iyi yaşam standartları bulmak için genç nüfusun kırdan kente göçüne bağlı olarak, ekonomik bakımdan aktif olmayan yaşlı nüfusun alanda kaldığı tespit edilmiştir. Bunun bir sonucu olarak, bölgede eskiden büyük bir ekonomik faaliyet olarak tespit edilen hayvancıllk faaliyetinde önemli bir azalma belirlenmiştir. Türkiye'nin birçok dağllk bölgesinde benzer durum, ülkenin et ve süt ürünlerinin sağlanmasını olumsuz yönde etkilemektedir. Bunun gibi sorunların çözümü için özellikle dağlık bölgelerde ekonomik ve çevresel sürdürülebilirliğe dayalı politikaların uygulanması önerilmektedir..

Anahtar sözcükler: Çevre koruma, nüfus dinamikleri, sürdürülebilir kalkınma, dağllk alanlar, Türkiye.

\section{Introduction}

Mountain areas of the world are susceptible to a number of issues including difficult access, economic and political marginality, out-migration, environmental sensitivity and diversity of livelihood (Price, Jansky and Iatsenia, 2004). Studies of the demographic changes and their relationship to environmental degradation, social and economic instability in rural and mountain areas have been conducted by scholars from various disciplines. Out migration is often considered as a direct response to environmental degradation and rural poverty in mountain areas (Grau and Aide, 2007; Qi et al. 2008; Qin 2010; Robson and Nayak, 2010). It has been found that basic surviving strategy of individuals, households or the rural communities during the scarcity of resources is outmigration. Migration can be viewed as tactic for diversification of economic activities even during the presence of subsistence resources whereby a family assigns some of its labor for non-agricultural work (Hill, 1989). Rural communities of many mountain areas of the world find migration as the primary way to diversify their economic activities for a better living (Schoch et al, 2010).

Rural-urban migration in mountain areas and its compatibility with natural and socioeconomic environment is an issue of hot debate among the scholars of mountain areas research in the world. It is argued that out migration contributes in the sustainability of fragile mountain ecosystem as increasing inflow of remittances provided by the migrants play important role in poverty reduction, investment facilitation, raised productivity and reduction of environmental pressures. Moreover, rural out migration from mountain areas also contributes in ecological recovery and increase in biodiversity (Grau and Aide, 2007; Schoch, 2010; Khan and Somuncu, 2012). However, on the other hand, out migration and its incompatibility with natural, social and economic regimes is another issue which is well worth considering. Out migration causes the reduction of human capital and work force in the area which is considered fundamental in creation of economic capital (World Bank, 1995; Serageldin, 1996). Besides, resultant demographic, cultural and environmental change related to out-migration also change the institutional arrangements, social setting and value system in local communities (Khan and Somuncu, 2012). These facts are in contrast to the concept of sustainable development where a stable development is ascribed to development of economic, social and environmental capitals equally. It is obvious that in order to achieve sustainable development simultaneous achievement of social, economic, political and ecological goals is necessary (Hardoy et al., 1992).

Present study finds out the interrelationship among rural out migration and natural and socioeconomic environment in mountain community of district Kibriscik, Bolu provice, Turkey. The objectives of research are to identify the nature and extent of these relationships and associated changes as well as to identify the requirements for sustainable rural development in the area. It is the purpose of this article to shed light on these inter-linkages and thereby contribute to a broader understanding of rural out- migration and its effects on mountain areas, both from a socio-economic and an environmental point of view. The main focus of the research is to inquire demographic changes and resultant socio-economic and environmental issues and their analysis in context of sustainability.

\section{Study Area}

The study site selected for this research is district Kibriscik in the Bolu Province, located at Western Black Sea region of Turkey. District Kibriscik, with dense forest cover, is situated in Koroglu 

Kıbrıscık District, Bolu Province, Turkey

Mountain Range constituting a large part of Aladag river basin (Figure 1).With its rugged topography and scarcity of agricultural land the dominant economic activity in the area is livestock grazing and wood processing in the forests along with a small number of individuals working in service sector. The area is rich in forests, pastures and biodiversity and almost $52 \%$ of the land of district Kibriscik is covered with forests. Total area of the district including city center and all 22 villages is $621 \mathrm{Km}^{2}$ with an average height of $1100 \mathrm{~m}$ above sea level (http://www.kibriscik.gov.tr/). The population of district as of 2011 census is 3484 (www.tuik.gov.tr). The area is suffering from the lack of human capital as a result of increased out migration which further contributes negatively in the socio-economic setting of the rural communities. Many rural communities in Turkey in general and particularly Bolu Province are facing similar problems. However, Kibriscik is facing the problem of out migration and decline in live stock activity in a greater extent as compared to the other districts of Bolu province because of poor infrastructure and difficult to access.

In a previous research in the area it was found that local population of Kibriscik district has played important role in environmental degradation. People used to graze their animal herds inside forest area and cutting of trees for domestic purposes is performed throughout the area. Moreover, clearance of land for new agricultural fields is also observed. In conclusion, all of these practices have given ways to increased deforestation and erosion (Sahin, 1990). However, the situation has started to change in the following years when people migrated to areas with better employment opportunities. District Kibriscik is under the threat of lack of human capital and related socio-economic changes after the year 1980 (Khan and Somuncu, 2012). Rapid decrease in the population of the area has a negative effect on the pastoral quality of life and traditional transhumance activity that makes it a unique and attractive place. This situation is leading to a marginalization of local populations and increased socioeconomic disparities among local inhabitants (Khan and Somuncu, 2012).

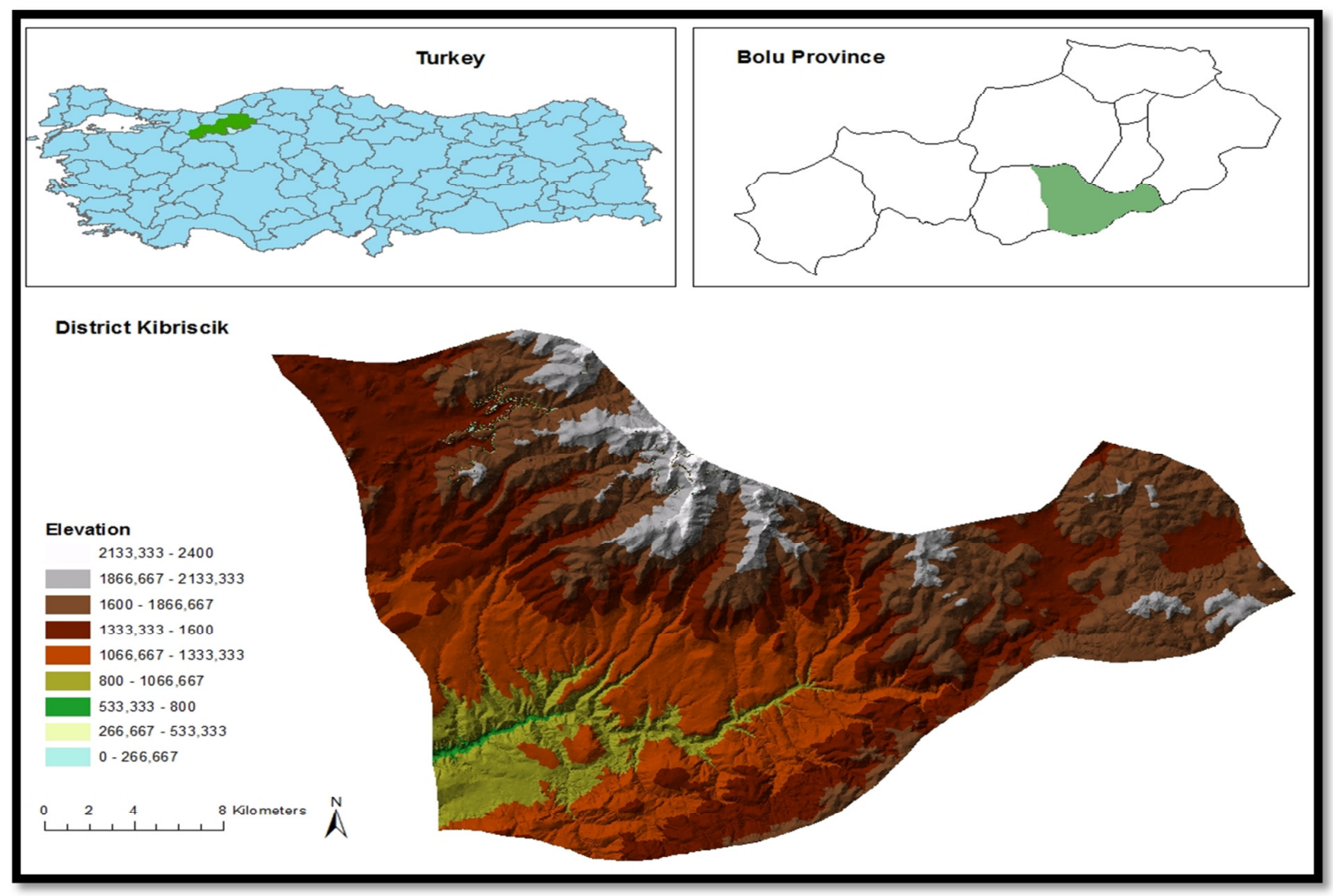

Figure 1. Location map of district Kibriscık (Khan and Somuncu, 2012) 


\section{Research Methods}

A mixed-methods approach to combine quantitative and qualitative methods is used in this study. The complex relationship of demographic dynamics and natural and socio-economic regimes necessitates the combination of multiple research methods. Data was collected through both primary and secondary sources. A structural context of the ongoing issue was provided by analysis of secondary socioeconomic and forest data from Turkish Statistic Bureau and Turkish Directorate General of Forestry. Structured and semi structured interviews were conducted along with key informant interviews as a qualitative method for in-depth understanding of socio-economic changes related to out migration. Interview questions were designed with the goal of in-depth insight to the issue and better understanding about the local people's perceptions regarding out migration.

Qualitative methods like semi structured interviews were used to acquire valid and detailed information from a smaller set of participants. A total of 201 people were interviewed during field work. Participants of interview were selected from all the villages and city center based on random sampling. The sample consisted of $85.5 \%(\mathrm{~N}=170)$ male and $15.4 \%(\mathrm{~N}=31)$ female participants. The respondents were asked questions regarding reasons behind out migration. Key informant interviews were conducted during field work to get detailed information about rural livelihood experiences, socio economic and environmental change and its effect on local population which provided a contextual background for the analysis of survey data. A total of 25 key informant interviews were conducted while key informants were selected from a range of categories including village leaders, school teachers, religious leaders or senior residents. All in-depth interviews were taped, recorded, and qualitatively analyzed to recognize mutual themes.

\section{Results and Discussion}

\subsection{Demographic Dynamics and Their Relationship to Natural, Social and Economic Regimes}

The rugged mountain topography has a vital role in scarcity of agricultural land in Kibriscik district. Moreover, lack of irrigation has also contributed in limited crop production in the area. Livestock grazing and working as labor in forests is primary source of living for the local village population. A small number of people are engaged in service sector and business in city center. Lack of any alternative economic opportunity is an important push factor that has forced people to migrate for diversification of their economic activities. The analysis of the population statistics during 19352010 has revealed that population of area increased steadily from 1935 to 1980 . However, after 1980, the population started to decline continuously (Figure 2).

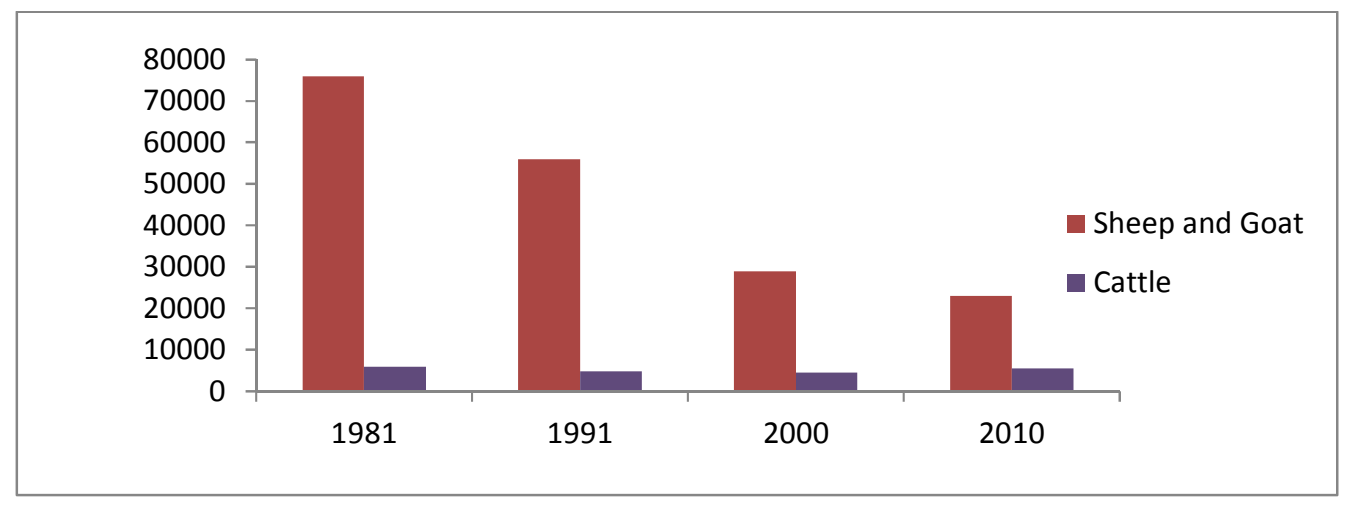

Source :( www.tuik.gov.tr)

Figure 2. Population change in district Kıbrıscık (1940-2010) 
Local people stared to send one or two members of the family to the bid cities for diversification of economic resources at first. The situation changed dramatically with the passage of time and whole family started to migrate to big city centers for better living standards. Forest policy has also said to be contributed in the decline of livestock activity in the area. It was revealed that sanctions made by forest officials about prohibition of grazing activity inside or near the forest area has forced people to abandon the activity. Many people engaged in livestock activity relinquished after getting lot of losses. During field work a total of 201 persons from different age and interest groups were interviewed for provision of first-hand information regarding process of migration in the area. Information regarding demographic factors like gender, age, education level and occupation of the participants has been given in Table 1.

Table 1. Demographic characteristics of the interviewees

\begin{tabular}{|c|c|c|c|c|}
\hline \multicolumn{2}{|c|}{ Demographic Characteristics } & $\begin{array}{l}\text { Number of } \\
\text { Persons }\end{array}$ & $\%$ & Total \\
\hline \multirow[t]{2}{*}{ Sex } & Male & 170 & 84,5 & 201 \\
\hline & Female & 31 & 15,5 & \\
\hline \multirow{6}{*}{ Age Group } & $15-24$ & 15 & 7.4 & \\
\hline & $25-34$ & 20 & 9.9 & \\
\hline & $35-44$ & 42 & 20.8 & \\
\hline & $45-54$ & 40 & 19.9 & \\
\hline & $55-64$ & 45 & 22.3 & \\
\hline & $65+$ & 39 & 19.4 & \\
\hline \multirow[t]{7}{*}{ Education Level } & İlliterate & 5 & 2.4 & 201 \\
\hline & Literate & 21 & 10.4 & \\
\hline & Primary School & 106 & 52.7 & \\
\hline & Middle School & 23 & 11.4 & \\
\hline & High School & 38 & 18.9 & \\
\hline & University Degree & 3 & 1.4 & \\
\hline & Other & 5 & 2.4 & \\
\hline \multirow[t]{8}{*}{ Occupation } & Agricultural Activity & 88 & 43.7 & 201 \\
\hline & Government Servant & 15 & 7.46 & \\
\hline & Private Sector & 29 & 14.4 & \\
\hline & Retired & 40 & 19.9 & \\
\hline & Student & 8 & 3.9 & \\
\hline & House Wife & 13 & 6.4 & \\
\hline & Jobless & 3 & 1.4 & \\
\hline & Other & 5 & 2.4 & \\
\hline
\end{tabular}

It is observed that most of people have migrated permanently after finding a reasonable job outside the district leaving behind the elder ones. These people come to visit their homelands occasionally. Better living standards, easy access to education and health facilities, and increased employment opportunities are considered the main reason for migration. Often stated reason for looking for employment outside the district was lack of suitable employment opportunities in the area. A person after getting good education also demands a job according to his level. Further stated reasons of migration and finding a job were as follows: easier work than in agriculture and secure income. It is stated that young people want insurance and security while agriculture activities do not provide such kind of security. This situation is explained by a farmer from Taslik village as: 
“.........my son is working in Istanbul on minimum wages. If he works here at village he can earn much more money. But city life is fascinating; work is easy and secure than village, and his children have better access to education and other facilities of life."

It is found that people having their own settled businesses and the aged ones are satisfied from their livings. However, people with low income, no access to credit and no alternative employment have a strong thought to migrate from the area. The main barriers behind their migration are lack of vacancies, tough competition and lack of professional skills. Most of the young people stated as:

“........... I did not find any opportunity to leave my area. I will flee at first priority on getting any opportunity. Village life is not attractive. Animal herding and agriculture work is too hard. There is no security and insurance of job. I am not satisfied from my living standard and want to improve it."

Majority of young population prefer to migrate from the area due to lack of resources in home town. This loss of young community members that are of a productive age has had an important effect on the age-sex structure of those left behind. There has been an obvious change in the number of economically active population aged 15 to 65 . While the proportion of residents over 65 years of age has increased, the number of children under the age of 15 has decreased to a significant level (Figure $3)$.

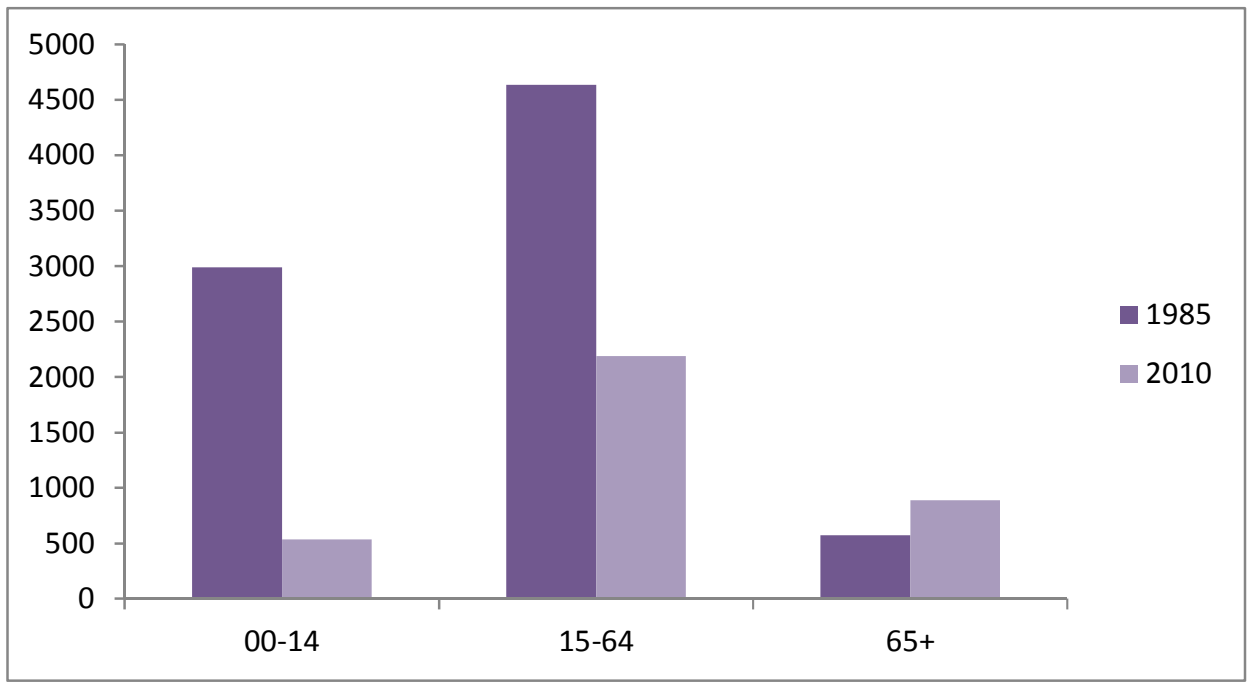

Figure 3. Population age groups of year 1985 and 2010

Source :( www.tuik.gov.tr)

\subsection{Increase in Forest Land Area}

It is argued that resource dependent communities used natural resources in unsustainable manner resulting in ecosystem destruction. Out migration is considered helpful in sustainability of fragile mountain environment. Protection of natural environments while sustaining a growing population requires high agricultural yield per hectare. If not, most or all natural resources like forest land and meadows would have to be transformed to agriculture land. Therefore, by migrating to big city centers, where the population consumes agricultural products from more well-organized systems, migrants help to preserve land for nature and conserve natural ecosystems in mountain regions. It has been assumed that local population of Kibriscik district has played important role in environmental 
degradation. People used to graze their animal herds inside forest area and cutting of trees for domestic purposes is performed throughout the area. Moreover, clearance of land for new agricultural fields is also observed. In conclusion, all of these practices have given ways to increased deforestation and erosion.

According to data provided by Turkish Directorate General of Forest, the forest land has increased continuously over the time. Afforestation campaigns are also being successful in order to combat erosion. New plants are being planted in abandoned land. According to statistics, the forest cover has increased from 30174.2 hectares to 32839 hectares by a percent increase of 8.8 during the years 1968 to 1986 . However, forest cover increased from 32839 hectares to 33382.6 hectares by $1.65 \%$ during years 1986 to 2005 (Figure 4). It is assumed that this increase in forest area is directly related to decrease of population in the area. Moreover, strict forest policy regarding animal grazing and illegal cutting of trees inside the forest land also contributed at significant level.

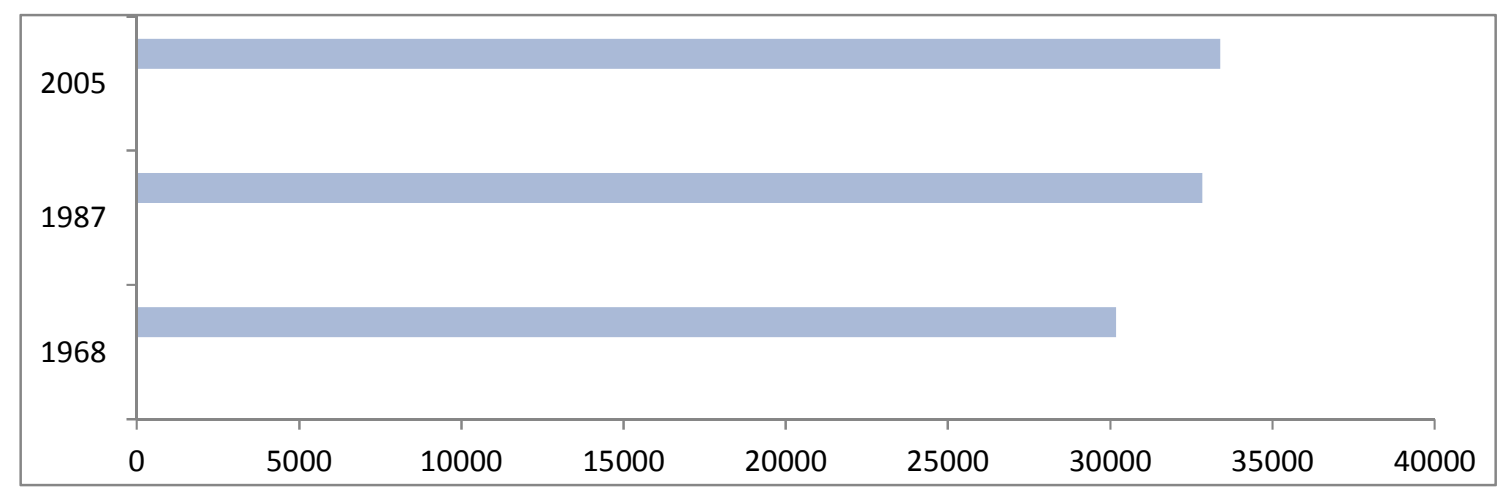

Figure 4. Increase in forest cove during 1968-2005

Source: Directorate general of forests, Turkey

Although migration has played an observable role in conservation of natural resources and environmental sustainability but associated negative consequences make the situation unhealthy. It is argued that the constructive aspects of rural-urban migration are not without harmful concerns. Rural communities lose human capital, mainly young people who are attracted to education and job opportunities in urban centers. This often results in losses of traditional knowledge and sociocultural values. In addition, the local social structure often changes as males migrate, leaving communities with children, women, and the elderly affecting the local environment. Kibriscik district is not an exception too.

\subsection{Decline in traditional livestock activity}

In Kıbriscık district, traditionally a family's income was calculated on the basis of number of heads of livestock it owns. Livestock was considered important for maintaining self-sufficiency due to the milk products and meat it provides. Moreover people made much investment on livestock in previous years because livestock was assumed to serve as an investment fund that increased itself through natural reproduction and can be sold whenever cash is needed. It was a customary practice by most of households to handover their animals to relatives, friends or a professional herder during summer. There was a trend of transhumance and in summer season majority of families with their herds shifted to summer pastures for almost 3 months. In winter season the herders moved towards down the valley areas. Moreover, customarily, livestock had also played important role in generation of seasonal employment for several local herders. 
However, in recent years, livestock activity, once served as backbone of economy of the area, has declined to a great extent. Increased out migration of young people and abundance of aged population in the area are important factors in this decrease. The number of cattle, sheep and goat are continuous to decrease as compared to previous years. Moreover, traditional activity of transhumance is also decreased and very few households take their herds to summer pastures. A local resident of village Karacaoren explained this change in traditional practice as: In my village once more than 70 households performed transhumance activity and stayed at mountain pastures with their herds but now only 5 to 7 families used to visit summer pasture. Mostly people come for enjoying and spending holidays."

According to statistics sheep and goat production is declined from 75880 heads in 1981 to 23010 heads in 2010 by $70 \%$. On the other hand cattle production is decreased from 6000 in 1981 to 5463 in 2010 by $9 \%$. (Figure- 5) Cattle production in the area is generally low as compared to sheep and goat production throughout the history. Most people rear cattle for domestic use and commercial.

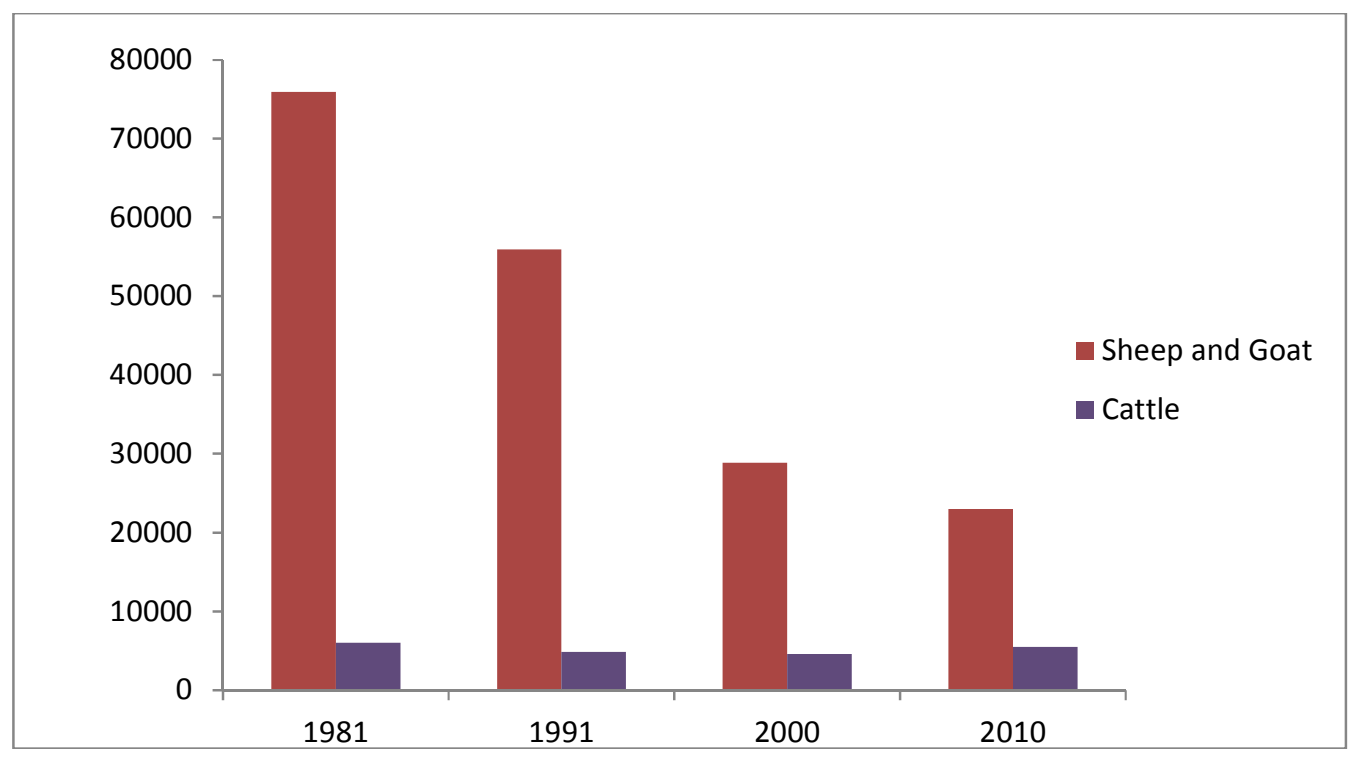

Figure 5. Decrease in livestock numbers with the passage of time

Source: www.tuik.gov.tr

Similar situations prevail in many mountain areas of the country. As a result country' overall production of meat is being affected. According to recent statistics it is found that beef production of Turkey from year 2008 to 2009 has decreased by \% 14.5 while sheep mutton and goat mutton has decreased by $22.9 \%$ and $15.1 \%$ respectively. Therefore, Turkey, once an exporter of meat, has to decide to import meat and animal from U.S and European countries (Karakus, 2011).

\subsection{Reduction in cultivated land and agricultural production}

Agricultural land is also decreased as most of the people have abandoned their fields. During the years 1995 to 2010, Vegetable fields are decreased by 97\%, crop land decreased by $21 \%$ while fruit garden land area decreased by $47 \%$ (Fig-6). Consequently, agricultural production is also decreased. 
Rural Urban Migration in Mountain Areas and its Compatibility with Natural, Social and Economic Regimes: A Case of Kıbrıscık District, Bolu Province, Turkey

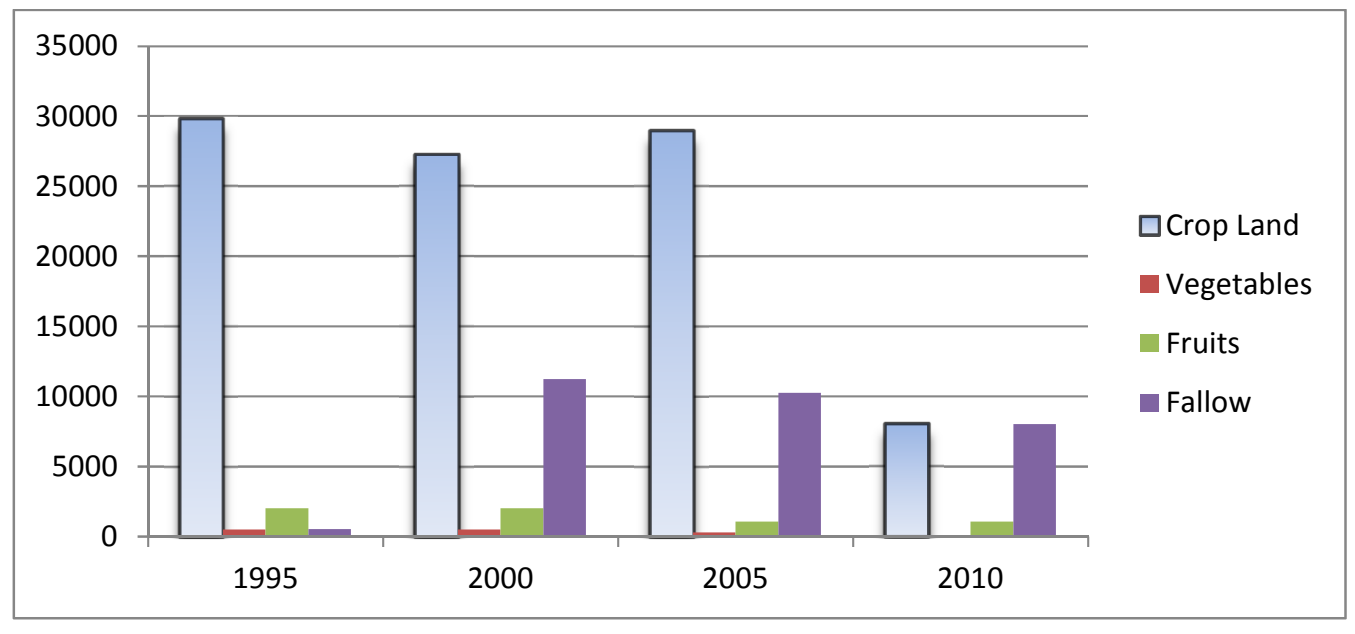

Figure 6. Reduction in cultivated land in district Kibriscik

Source: www.tuik.gov.tr

Most of the people pointed out absence of work force as primary reason of decline in agricultural production. An old villager of village Geris answered the question as:

“......... I have agricultural land but do not practice farming activities. I have no work force available and it is not possible for me to work alone."

In addition to abandonment of agricultural field due to migration other factors like scarcity of suitable agricultural land and little or no irrigation availability are also play important role in decline of production.

\section{Conclusion}

Mountains areas cover a significant portion of the world's land area and their valuable resources have played vital role in sustainable development. However, the specific challenges of development in mountains are rarely reflected in national policies of many countries of the world (Somuncu, 2011). Only a few countries have adopted coherent policies that address these challenges from a mountain perspective. In order to formulate effective policies for sustainable utilization of mountain resources it is necessary to understand the specific issues related to mountain areas. Rural out migration from mountain areas is a topic of considerable attention. Although agriculture activities remain central for rural economy worldwide, in recent years livelihood research has observed a worldwide trend towards the diversification of household income sources through migration (Schoch, 2010). Rural out migration from the mountain areas has both positive and negative aspects. It has proved beneficial in terms of environmental sustainability while on the other hand it has negative impacts on social and economic sectors.

In this article we used a case study from mountain area of Turkey to examine impact of rural out migration of natural, social and economic sectors. It is found that out migration has proven helpful and substantial increase in forest land has observed along with significant decrease in erosion. Present research has tried to highlight issue of out flow of human capital from the mountains and its negative effects on social and economic system. It is observed that due to increased out migration from the area, which has much economic potential, a change in traditional economic and social setup has been emerged. This change and associated issues are not compatible to the ideology of sustainable development. Therefore, it is necessary to formulate rural development policies focusing on social, environmental and economic values equally. It is necessary to utilize the valuable potential of mountain areas in a sustainable manner and to find out the alternative income opportunities for local population. 


\section{Ashfaq Ahmad Khan ve Mehmet Somuncu}

\section{References}

Directorate General of Forests, Turkey, Orman Amenajman Planı (1968, 1987, 2005)

Grau, H. R., and Aide, T. M. 2007. Are rural-urban migration and sustainable development compatible in mountain systems? Mountain Research \& Development, 27(2): 119-123.

Hardoy J, Mitlin D, Satterthwaite D. 1992. Environment Problems in Third World Cities. Earthscan: London.

Hill, A. 1989. "Demographic responses to food shortages in the Sahel." Population and Development Review, Supplement to Vol. 15. Eds. Geoffrey McNicoll and Mead Cain. New York: Population Council and Oxford University Press.

Karakus, K. 2011. Türkiye'nin Canlı Hayvan ve Kırmızı Et İthaline Genel Bir Bakış. Iğdır. Univ. J. Inst. Sci. \& Tech. 1(1): 75-79.

Khan, A.A., Somuncu, M. 2012. Dynamics of rural out migration and environmental conservation: A dilemma of Sustainable Development of mountain community of district Kibriscik, Province of Bolu, Turkey. New Horizons in Science and Technology 1(3): 59-64. http://www.insii.com

Kibriscik Kaymakamligi Resmi Websitesi: http://www.kibriscik.gov.tr/ Accessed Jul. 2011

Price, M.F., Jansky,L., Iatsenia, A.A., (eds.),2004. Key Issues for Mountain Areas, United Nation University Press. USA.

Qi, L., Chunyue, Y., and Juan, L. 2008. Rural-urban Migration Rural Household Income and Sustainable Development in Rural Areas of China. Chinese Journal of Population, Resources and Environment 6 No.2.

Qin, H. 2010. Rural-to-Urban Labor Migration, Household Livelihoods, and the Rural Environment in Chongqing Municipality. Southwest China. Human Ecology, 38. 675-690.

Robson, J.P., and Nayak, P.K. 2010. Rural out-migration and resource-dependent communities in Mexico and India, Population and Environment,32:263-284.

Sahin, C. .1990. Aladag Cayl Havzası'nda Cevre Kosullarl ve Bunlarla İlgili Bozulmus Dogal Dengenin Yeniden Kurulmasına Illişkin Sorunlar ve Cözüm Yolları, Atatürk Kültür, Dil ve Tarih Yüksek Kurumu, Cografya Dizisi Sayı:1. Ankara.

Schoch, N., Seimann, B., and Thieme, S. 2010. Migration and animal husbandry: Competing or complementary livelihood strategies. Evidence from Kyrgyzstan, Natural Resources Forum, No: 34: 211-221.

Serageldin, I., 1996. Sustainability and the wealth of nations: steps in an ongoing journey. Environmentally Sustainable Development Studies and Monographs Series No. 5. World Bank, Washington, DC.

Somuncu, M., 2011, Sustainable Development in the Eastern Black Sea Mountains: Present State and Perspectives, pages 215-225 in Sustainable Development in Mountain Regions: Southeastern Europe, ISBN: 978-94-007-0130-4

Turkiye Istatistik Kurumu, www.tuik.gov.tr. Accessed Jul. 2011.

United Nations, 1992., Agenda 21: Chapter 13: Managing fragile ecosystems: Sustainable mountain development, UN Doc. A/CONF. 151/26 (Vol. II), 13 August. Washington D.C.: United Nations.

World Bank, 1995. Monitoring Environmental Progress: A Report on Work in Irogress. World Bank, Washington, DC.

www.un-documents.net/ Accessed. Aug. 2011

http://www.istanbul-city-guide.com/map/Turkey/Bolu-Map.asp Accessed. Feb. 2012 